\title{
Use Wood - Combat Climate Change
}

\section{S K Nath*}

Ex-Jt. Director, Indian Plywood Industries Research and Training Institute, Bangalore, India

*Corresponding Author: S K Nath, Ex-Jt. Director, Indian Plywood Industries Research and Training Institute, Bangalore, India.

Received: March 13, 2019; Published: October 17, 2019

DOI: 10.31080/ASAG.2019.03.0682

\begin{abstract}
The most debated nonpolitical issue in the present world is perhaps the matter related to climate change. Deforestation, industrialization and excessive use of coal and petroleum have been referred as the major cause leading to climate change. Resource from which construction/consumable material and energy being made are from minerals, coal and petroleum which are limited in earth storage and will be exhausted one day or other. Timber alone can be used for construction as well as burnt to produce energy. Trees store carbon and release oxygen $-1 \mathrm{M}^{3}$ of wood stores 0.9 ton $\mathrm{CO}_{2}$ and substitutes 1.1 tons of $\mathrm{CO}_{2}-\mathrm{a}$ total of 2.0 tons of $\mathrm{CO}_{2}$. Thus a total of 2.0 tons of $\mathrm{CO}_{2}$ can be substituted by $1 \mathrm{M}^{3}$ of wood. For non-conventional energy, the ultimate source, directly or indirectly, is the sun. The total radiation (energy) reaching to earth from sun is $5.7 \times 10^{24} \mathrm{~J}$ per year and total energy (electricity/heat) produced by burning coal/petroleum per day is $54.37 \mathrm{EJ} /$ year (exa-joule, $\mathrm{EJ}=10^{18} \mathrm{~J}$ ). The best way for tapping solar energy is by growing trees which can give food, material as wood and energy on burning.

The major question is whether the vegetative system alone can meet the entire nutrient, energy and material need of living kingdom on the earth. For the nutrient supply the answer is 'YES' and already doing so. The living consumers whether herbivore or carnivore, whether in aquatic of terrestrial system, are dependent on, directly or indirectly, on plants which prepares food through photosynthesis or chemosynthesis by utilizing solar energy. The average residence time in natural forest from 20 - 120 years can be brought down to 5 - 10 years with fast growing plantation timber. Agricultural residue, which can also be converted into structural component, can be generated in 3 to 12 months. Now it is the right time to think and utilize what scheme might be used to manage the resources in nature for material and energy.
\end{abstract}

Keywords: Climate Change; Non-Conventional Energy; Photosynthesis

At the down of civilization, human being was solely dependent on nature for food. Killing of birds and animals or other living being by hunting and gathering fruits, vegetables were the means to get food. As the civilization advanced, man learnt cultivation to grow cereals and the art of farming/rearing animals for food. Hunting for livelihood became heinous profession. In today's world, we cannot dream of feeding the world population without producing food by cultivation/farming/rearing etc.

Shelter is another inseparable necessity of human livelihood. Wood from forest, metal made from minerals, cement made from soil, various synthetics like plastics made from petro-products are the several materials used for construction of houses. For making shelter, human being are still remained dependent on naturally occurring resources.

Timber, mud and stone were the first choice to use as housing components to build shelter. As the housing technology advanced, materials like brick, cement, metal and synthetic were added as housing components. Wood can be used as sole component in making houses or many other structural materials (bridge, tower etc.) and such uses have been favoured since long because wood is easy 
to process, even with simple hand tools, higher weight to strength ratio and can be shaped to fit into thousands of end use applications. However, the use of wood, in excess to growing led to severe deforestation around the world. This in turn led to global warming, emission of excess greenhouse gases, pollution of air, water etc. This has become the reason of grave concern for environmentalists and people in general. Various Governments/authorities round the world has put ban on felling of trees in forest and use of wood and wood product in many sectors. However, use of other housing and structural materials like metal, brick, cement, plastic, remained unabated, rather boosted to replace wood. All these components, for their production and application require high energy and emits poisonous gases and discharge harmful effluents creating severe environmental deterioration.

Sun rays heats the earth's surface during day. Part of the heat is radiated during night as infrared radiation. However as it is less powerful than the incoming radiation from the sun, it is unable to cross the barrier of specific atmospheric gases called greenhouse gases (GHG). The most significant greenhouse gas is carbon dioxide $\left(\mathrm{CO}_{2}\right)$. Other greenhouse gases include water vapour $\left(\mathrm{H}_{2} \mathrm{O}\right)$, methane $\left(\mathrm{CH}_{4}\right)$, nitrous oxide $\left(\mathrm{N}_{2} \mathrm{O}\right)$, Chlorofluoro-carbon (CFC) and sulpher hexafluoride $\left(\mathrm{SF}_{6}\right)$. However, excess deposition of GHG should not be confused with natural greenhouse effect which keeps Earth's mean temperature around $15^{\circ} \mathrm{C}$ to $18^{\circ} \mathrm{C}$ [5].

Since the beginning of industrial revolution there has been sharp increase in greenhouse gases into the atmosphere mainly due to $\mathrm{CO}_{2}$ from burning of fossil fuel. About $55-70 \%$ additional greenhouse effect is caused by $\mathrm{CO}_{2}$. According to most optimistic estimates, the increase in $\mathrm{CO}_{2}$ in the atmosphere is by $0.5 \%$ a year. As a result, the mean temperature rise is expected to be 0.1 to $0.4^{\circ} \mathrm{C}$ per decade during first half of this century.

The addition of $\mathrm{CO}_{2}$ to the atmosphere is about 8 billion tons per year mainly from burning of fossil fuel. The current vision of development requires energy of which $85 \%$ comes from burning of fossil fuel. Hence a reduction or stabilization of current level of emission of $\mathrm{CO}_{2}$ from burning of fossil fuel would involve politically unacceptable cuts in energy consumption. This has been reflected during signing of Kyoto Protocol by US which accounts for highest emission of $\mathrm{CO}_{2}$ in the world.

Deforestation affects environment and climate change. This concept has gone so deep into people's mind, specially through ex- treme environmentalists lobby, that felling of trees in forest or in public place is treated as criminal as poaching an endangered species of animal. The other effect of preaching against use of timber is to promote use of non-wood products made from metal, cement, ceramic, plastic and other synthetic polymeric products obtained from petrochemicals. However the use of non-wood products has the limitations:

1. Production and use are high energy consuming,

2. Creates harmful effluent, solid waste, greenhouse and other poisonous gases during production and usable life,

3. Synthetic polymers are not bio-degradable and hence degrade soil and water when dumped after useful life.

4. Raw materials of all these products are non-renewable and have limited stock on the earth.

The following tables show the quantitative measures of the above said limitations:

\begin{tabular}{|c|c|c|c|}
\hline $\begin{array}{l}\text { Sl. } \\
\text { No. }\end{array}$ & Resource & Reserve & $\begin{array}{l}\text { Duration of } \\
\text { availability }\end{array}$ \\
\hline 1 & Natural gas & $\begin{array}{c}66609 \text { Trillion cubic } \\
\text { feet }\end{array}$ & \\
\hline 2 & Coal & 847 Billion tons & 118 years \\
\hline 3 & Petro - oil & $\begin{array}{l}1.77 \times 10^{11} \mathrm{~m} 3 \\
(1.114 \text { barrel })\end{array}$ & 120 years \\
\hline 4 & $\begin{array}{c}\text { Iron } \\
\text { (2 billion m.ton } / y r \\
\text { extraction) }\end{array}$ & $5 \%$ of earth & 64 years \\
\hline 5 & $\begin{array}{c}\text { Line stone } \\
\text { (115000 m..ton/yr } \\
\text { extraction) }\end{array}$ & $\begin{array}{l}10 \% \\
\text { World sedimentary } \\
\text { rock }\end{array}$ & Adequate \\
\hline 6 & Aluminium & $\begin{array}{c}8.3 \% \text { of earth's } \\
\text { weight } \\
\text { (earth's mass = } \\
5.972 \times 10^{21} \text { tons) }\end{array}$ & Adequate \\
\hline 7 & Uranium & $\begin{array}{c}35 \mathrm{~m} \text { tons as mineral } \\
\text { on earth crust }\end{array}$ & \\
\hline 8 & Sea Plankton & $\begin{array}{l}4.6 \text { billion tons in } \\
\text { sea water }\end{array}$ & \\
\hline 9 & Tritium & $\begin{array}{c}225 \text { kgs produced } \\
\text { in US }\end{array}$ & \\
\hline
\end{tabular}

Table 1: Raw material reserve.

Source: Wikipedia, US Energy Information Administration, US Geographical Survey $[8,9]$. 


\begin{tabular}{|l|c|}
\hline Commodity & $\begin{array}{c}\text { Net energy required } \\
\text { [million Kcal (oil equivalent) } \\
\text { per ovendry ton }\end{array}$ \\
\hline Lumber & 0.73 \\
\hline Wood fence post & 1.0 \\
\hline Plywood & 1.5 \\
\hline MDF & 2.14 \\
\hline Concrete slab & 2.15 \\
\hline Concrete block & 2.21 \\
\hline Clay brick & 2.28 \\
\hline Steel stud & 12.68 \\
\hline Steel fence post & 12.68 \\
\hline Aluminium siding & 50.51 \\
\hline Carpet and pad & 9.37 \\
\hline
\end{tabular}

\begin{tabular}{|l|c|c|}
\hline Elements & Emission & Absorption \\
\hline Combustion of fossil fuel & 6.3 & - \\
\hline Deforestation & 1.6 & - \\
\hline Total & 7.9 & - \\
\hline Seas and other water bodies & - & 2.3 \\
\hline Afforestation and increased biomass & - & 2.3 \\
\hline In to the atmosphere & - & 3.3 \\
\hline Total & - & 7.9 \\
\hline
\end{tabular}

Table 3: Global Carbon Balance (Billion tons of carbon/year).

The average life of wood products varies between 2 months for newspaper and 75 years for structural wood. Thus any volume of wood storage will reduce $\mathrm{CO}_{2}$ in the atmosphere. Thus increasing the use of wood and wood products is one of the simple way of reducing climate change.

Table 2: Energy required for manufacture of Structural Products [10].

If the energy for production of non-renewable comes from burning fossil fuel, for each litre of fuel burnt will produce an extra amount of $2.24 \mathrm{kgs}$. and dump $\mathrm{CO}_{2}$ to the atmosphere. However, if fuel oil is replaced by natural gas, an amount of gas which produces equal quantity of heat adds only $1.65 \mathrm{kgs}$. of $\mathrm{CO}_{2}$ - an amount significantly less. Then again, production and transport, which requires liquid fuels, will consume 13 percent of the extra energy.

There are two ways to reduce $\mathrm{CO}_{2}$ in the atmosphere - either by reducing emissions or by removing $\mathrm{CO}_{2}$ and storing it, that is reducing carbon sources and increasing carbon sink. Growing trees absorbs $\mathrm{CO}_{2}$ and produces $\mathrm{O}_{2}$. On an average a typical tree absorbs, through photosynthesis, the equivalent of 1 ton of $\mathrm{CO}_{2}$ for every cubic meter growth, while producing the equivalent of 0.7 ton of oxygen [5].

Carbon is being exchanged continuously between the different carbon sources and sinks in a process call "carbon cycle". The global carbon balance is given in table 3 .

$\mathrm{CO}_{2}$ stored in wood continues to be kept out of atmosphere throughout the initial life of wood products and then beyond, through reuse and recycling (eg. Solid wood to particle board) and finally carbon in wood is returned to atmosphere as $\mathrm{CO}_{2}$ by burning or decomposition.

If the forest is left entirely to nature, it will attain a climax stage supporting the soil with the maximum amount of biomass fertility under prevailing condition of rainfall and temperature. Although natural regeneration will occur the dead and dying trees will decay or burnt, emitting $\mathrm{CO}_{2}$ from the stored carbon. Growth is matched by decay and with no forest management, there would be no increase in carbon storage.

Encouraging use of wood products can act as a greener alternative to more fossil fuel intensive materials. Substituting a cubic meter of wood for other construction materials (concrete, bricks) results in significant $\mathrm{CO}_{2}$ savings. The combined effect of carbon storage and substitution means that $1 \mathrm{M}^{3}$ of wood stores 0.9 ton $\mathrm{CO}_{2}$ and substitutes 1.1 tons of $\mathrm{CO}_{2}$ - a total of 2.0 tons of $\mathrm{CO}_{2}$. Thus more the wood products replace other materials, more the socalled "substitution effect" which further reduces $\mathrm{CO}_{2}$ in the atmosphere. $\mathrm{CO}_{2}$ reductions achieved by wood products are eligible under Art. 3.4 of the Kyoto Protocol and the wood working industries may be granted carbon credits in the framework of the emission trading schemes [6].

Wood energy is $\mathrm{CO}_{2}$-neutral and clean

Wood is excellent combustible material and has been source of energy since the dawn of human civilization. Wood energy can be derived from wood in raw form, bark, saw mill and shaving residues, residues from panel and furniture manufacturing units, forest residues and wood recovered from consumer products after end of useful life. 
Burning of wood provides carbon neutral substitute for fossil fuels. Since it only returns $\mathrm{CO}_{2}$ that has been taken from atmosphere for growing of trees, wood combustion does not contribute to global warming or greenhouse gases. Further wood contains little sulpher and nitrogen which contribute to acid rain and also it produces little ash. Thus wood energy is clean [5].

Energy in the form of heat and electricity is the most needed element required to keep flow of modern civilization. Modern life style will be paralyzed without supply of energy in either of the form. Coal and petroleum are the major source from which energy is being harnessed. Other minor sources are wood and agricultural residue. Energy is also generated from atomic fission, hydro power, wind power and solar radiation. But these are relatively minor sources.

To keep up with the present status of life or better, both materials (as mentioned) and energy (heat, electricity) are required. Resource availability indicates that reserve on the earth is limited to 100 - 150 years. What then? In fact, human civilization has reached such a stage with respect to sourcing of energy it is comparable to human in pre-historic days when they adopted practice of cultivation for growing food abandoning collecting/hunting food from natural resources.

The crisis of energy had been felt long back and search for energy from renewable or perennial sources had been initiated. Success has been obtained in tapping energy as solar energy, wind energy, hydro energy to produce both heat and electricity. Nuclear energy is another potential and successful area. But till today total energy produced from all these sources compared to energy produced from conventional sources like coal and petroleum is very negligible.

The following table shows the potential availability and present exploitation of renewable energy source in India.

\begin{tabular}{|l|c|c|c|}
\hline Source/Technology & Units & $\begin{array}{c}\text { Potential/ } \\
\text { Availability }\end{array}$ & $\begin{array}{c}\text { Potential } \\
\text { Exploited }\end{array}$ \\
\hline Biogas plant & Million unit & 12 & 3.22 \\
\hline $\begin{array}{l}\text { Biomass based } \\
\text { power }\end{array}$ & MW & 19500 & 384 \\
\hline Efficient wood stoves & Million unit & 120 & 33.86 \\
\hline Solar energy & MW/Km² & 20 & 1.74 \\
\hline Small hydro & MW & 15000 & 1398 \\
\hline Wind energy & MW & 45000 & 1367 \\
\hline $\begin{array}{l}\text { Energy recovery } \\
\text { from waste }\end{array}$ & MW & 1700 & 16.20 \\
\hline
\end{tabular}

Table 4: Renewable Energy Source: Potential/Availability and Exploited.

Source: TER
It must be noted that renewable energy capacity is always much larger than how it can actually deliver. It is variable in supply as far as wind and solar are concerned and there is yet no inexpensive way to store and use the energy later. At present all renewable energy is expensive compared to present ones. It is unlikely in the foreseeable future that renewable energy can meet the vast additional needs of energy. It can only supplement supply.

Whenever and wherever scientists have looked for non- conventional energy, the ultimate source, directly or indirectly, is the sun. The total radiation (energy) reaching to earth from sun is 5.7 $\mathrm{x} 10^{24} \mathrm{~J}$ per year and total energy (electricity/heat) produced by burning coal/petroleum per day is $54.37 \mathrm{EJ} /$ year. The best way for tapping solar energy is by growing trees which can give material as well as energy. Growing trees and use it as material and energy source will create a cycle for rotation of carbon in atmosphere, sink and store. If wood is burnt it will not dump extra carbon as carbon dioxide will be removed from air by growing of trees. Use of conventional fuel like coal/petroleum/natural gas infuses carbon dioxide and other acidic gases into atmosphere while burning. This does not happen while burning wood.

\section{An alternate thinking is now necessary}

In ancient time, as man adopted the process of cultivation for growing food grain, hunting was treated as hated profession as well as cutting of trees; rather Aryan culture suggested worshipping of trees. Through experience man of today has learnt that how useful are trees and forest to keep the earth worth living. Felling of trees in forest is being treated as illegal and this has encouraged use of wood alternative like metal, cement, plastic, petroleum coal. Use of these materials has definitely helped in quick advancement of the human civilization but simultaneously made the soil, water bodies as well as air more and more polluted. If this continued at the present rate, days are not far when the world would be unsuitable for healthy living.

Nutrient and other materials are continually re-circulated within and among ecosystem and by and large there are no new inputs or losses from the planet. In terms of material the earth is a closed system. But both energy and materials are essential to ecosystem structure, function and composition. In terms of cycling of carbon, materials and energy can be inter-converted. Energy is used up and lost as heat as it moves through ecosystem and new energy is continually added to the earth in the form of solar radiation.

Can energy requirement of the world be met from solar energy only? Approximately $5.7 \times 10^{24} \mathrm{~J}$ of solar energy are irradiated to the earth's surface on an annual basis. Plants and photosynthetic organisms utilize this solar energy in fixing large amount of $\mathrm{CO}_{2}$ $\left(2 \times 10^{11}\right.$ tons $=3 \times 10^{21} \mathrm{~J} /$ year $)$, while amount consumed by human 
beings are relatively small $\left[3 \times 10^{20} \mathrm{~J} /\right.$ year], representing only $10 \%$ of the energy converted during photo synthesis $[1,2]$.

The low conversion of solar energy into primary energy source for human use is due to lack of effective conversion and storing system. Although, large amounts of solar energy are irradiated to the earth's surface, the effective energy concentration (energy/ unit area) of solar energy at any one point on the earth surface is small - only about $1 \mathrm{KW} / \mathrm{m} 2$ at most even at noon. Such low effective energy concentration limit the use of solar energy as a primary energy source and elevate the costs associated with its accumulation and transmission.

A team of Glasgow University scientists headed by Prof. Richard Cogdell are developing a process to make oil substitute by using "artificial leaf" technology - which is actually a twisted version of photosynthesis. Rather than producing organic sugar material from carbon dioxide as plant do, the scientists plan to produce hydrocarbon "fuel" which can be used in petrol engines to power cars, even ship and aeroplanes. Once oil reserve of the world runs out, we must have such portable liquid fuel which is renewable and sustainable for transport vehicles, ships and aeroplanes [3].

Still the big issue at the moment is the availability of most renewable energy source to make electricity. Prior to industrial revolution wood served as a major energy source. The industrial revolution gave rise to the wide-spread use of both coal and petroleum as energy source. However, all fuel prices, the world over, have been rising in line with those of oil and gas. With increasing quantity of energy requirement, more expensive sources of fuels are inevitable, like coal, LPG, petroleum, uranium etc.

We have no other choice but to look at the sun for ultimate need of energy and material. The life on the earth is surviving and has become sustainable because of sustainable supply of food. We are using the natural process - photosynthesis - to grow food as much as required. Food supply is nothing but cycling of material (mainly carbon in atmosphere) which are being synthesized by nature by using $\mathrm{CO} 2, \mathrm{H} 2 \mathrm{O}$ and solar energy. The basic organic molecule - glucose formed in this way is transformed into various organic compounds. These compounds are utilized by living being for livelihood. At the end of life, organic bodies decompose and carbon goes back to air and water or soil. Ultimately it is the absorption and radiation of solar energy which keeps the life on this earth sustainable
Nature is distinctly pointing out that energy cannot be sourced other than the sun in indefinite quantity for indefinite period. Today's major source of energy - coal and petroleum are nothing but creation of nature through photosynthesis and has buried during some prehistoric days and transformed into coal and petroleum. Unless we learn and adopt the art of tapping solar energy to meet our need for energy and remain increasingly dependent on stored source like coal and petroleum as source of energy, the end of civilization is not far off. Only the part of life sustainably and totally dependent on nature will survive, the rest of life on the earth, which is dependent on nature's stored energy and material, will perish.

Before the discovery of coal and petroleum, wood and agro residues were the only material to be burnt to generate heat. With the discovery of coal and petroleum, these fuels started replacing wood rapidly as fuel. Industrial revolution enhanced the use of coal and petroleum based fuel (diesel, petrol and natural gas). Automobiles, ships, aeroplanes are totally based on petroleum based fuel. LPG is rapidly replacing any other domestic fuel for their cleanliness and other advantages of use. Replacement of wood by other materials as fuel to generate heat and energy has been greatly augmented by growing environmental consciousness around the world for protection of forest.

Conservation of natural forest is necessary to maintain ecological balance, biodiversity, water sources and to combat global warming. If good consciousness does not work to restrict indiscriminate felling of trees or destroying forest, there is reason to impose strictest rule to ban on felling in the forest. But social need for wood cannot be denied.

To meet the social need for wood, almost all countries throughout the world have initiated plantation and supply wood to meet the demand from plantation. In some European countries, Canada and South America, Russia, the plantation is sufficient or surplus to meet the national demand for wood at the present rate of consumption. Most of the countries do not yet use wood for energy generation; although in many European countries energy sector has been advised to utilize $20 \%$ of wood as fuel. Many governments have announced subsidies for wood supply to energy producing units. This has, of course, raised great debate in some countries and is being strongly opposed by wood based industries. Of course, in those countries the opposition to utilization of wood for energy generation (by burning) is not an environmental issue but rather economical. Supply of wood to energy units at subsidized rate will 
affect the economy of running the wood based industries as well as the supply chain.

Compared to effect on economy of the wood based industries, the disturbance in supply chain of wood is more important because non-sustainable supply may lead to the question of survival of the industry. The question which needed to be answered: Is the net production of timber and consequently supply to both the wood industry and energy units is sufficient to do that on a sustainable basis? Going a step further, if we assume that due to short supply of coal and petro-fuel if all the countries in the world, adopts a common policy to utilize wood as source of energy, will the land surface on the earth is sufficient to produce enough trees to meet both the material need and energy need of the growing demand of the society?

The major question is whether the vegetative system alone can meet the entire nutrient and material need of living kingdom on the earth. For the nutrient supply the answer is 'YES' and already doing so. The living consumers whether herbivore or carnivore, whether in aquatic or terrestrial system, are dependent on, directly or indirectly, on plants which prepares food through photosynthesis or chemosynthesis by utilizing solar energy.

\begin{tabular}{|l|c|c|}
\hline Ecosystem Type & $\begin{array}{c}\text { Surface } \\
\text { Area } \\
\left(\mathbf{X 1 0}^{\mathbf{6}} \mathbf{K m}^{\mathbf{2}} \mathbf{)}\right.\end{array}$ & $\begin{array}{c}\text { Net Primary Veg- } \\
\text { etative Production } \\
\text { (Pg.) }\end{array}$ \\
\hline Forest & 31 & 48.7 \\
\hline $\begin{array}{l}\text { Woodland, grassland and } \\
\text { Savanna }\end{array}$ & 37 & 52.1 \\
\hline Desert & 30 & 3.1 \\
\hline Artic Alpine & 25 & 2.1 \\
\hline Cultivated land & 16 & 15.0 \\
\hline Human Area & 2 & 0.4 \\
\hline Other terrestrial & 6 & 10.7 \\
(chapparral, bogs, swamps, \\
mashes)
\end{tabular}

Table 5: Total Surface area on the Earth and Vegetative Cover.

$$
\mathrm{Pg}=\text { Pedagram }=10^{15} \mathrm{gm}=10^{9} \text { tons }
$$

Source: The flow of Energy: Primary Production to Higher Tropic Level: www.globalchange.umich.edu.
Net Primary Production (NPP) is calculated as annual harvest. In a cropland NPP and annual harvest can exceed annual NPP (for example, when a forest is cut down the harvest is of many years of growth), but we can still compute annual averages.

Nature, of its own, may not produce enough to feed all living being on the earth, but man has discovered cultivation where nature's own process of photosynthesis is being utilized to tap solar energy in carbon from air to prepare compounds to store energy and material supply (wood and others). On the land only human being commands about $40 \%$ of the total terrestrial NPP. This has probably never occurred before in earth's history. However, human use of marine productivity is relatively small. Moreover, although major fish stocks are heavily fished and many coastal areas are severely polluted, human impact on the seas is less than on land. As on today, a sustainable food chain has been established to all living consumers to supply form aquatic (sea, river, lake, fisheries) and terrestrial (natural or through cultivation). The sustainable food supply may continue indefinitely unless disturbed by demand supply gap.

Except human being, no other living being require additional energy other than through food and from sun rays. In respect of energy, supply is not sustainable and we are greatly dependent on sources which are stored in the earth. $80 \%$ of the energy necessary to run our society comes from fossil fuel. Fossil fuel is nothing but remains of surplus biomass which was buried for long period of time million of years back and had undergone bio-chemical changes under heat and pressure. It is impossible that under the present rate of consumption of bio-mass that any bio-mass deposit is pilling-up anywhere on the earth. Stored fossil fuel will be exhausted sooner or later and no fresh store of fossil fuel is going to be created unless the human civilization is completely destroyed and life starts afresh on the earth.

Use of inorganic material like stone, minerals excavated from earth is being practiced by human being since centuries. Use of stone has been limited due to non-availability and competition from more suitable structural products from metal and cement. Mining is going to be restricted in many places.

At the first instance, total dependence on timber for energy and material may look impossible and future may look bleak. But looking at the sustainable eco-system in the ocean, the above question may be answered. The sustainable supply is not a matter of the quantity in stock at a particular time but the all important aspect of "TIME". Even though the total standing trees may be small, the RATE at which plantation trees produced may be very large. Thus 
over time it is the total number of plantation trees that is being produced, from whatever source or species may be, that is important for sustainable supply [4].

A very good example is seen in the ocean where most of the primary production is concentrated in microscopic algae. Algae have short life cycles, multiply rapidly, do not generate much biomass relative to their numbers and are eaten rapidly by herbivores. At any given point of time, the standing crop of algae in an ocean is likely low, but the turnover can be high. Algae populations can double in few days, whereas zooplankton might only reproduce once a year [4].

Similarly average residence time in natural forest ranges from $20-120$ years, which can be brought down to $5-10$ years with fast growing plantation timber. Agricultural residue, which can also be converted into structural component, can be generated in 3 to 12 months. Now it is the right time to think and utilize what scheme might be used to manage the resources in nature.

\section{Bibliography}

1. Renewable biological systems for alternative sustainable energy production: FAO Corporate Document Repository (year?).

2. Hall DO. In "Biomass for Energy" Ed. Hall UK Section of International Solar Energy Society, London D.0 (1979): 1-18.

3. "Artificial leaf tech to power cans" - Note on work of Prof. Richard Cogdell, Glasgow University, publish in Times of India (2012).

4. Flow of energy.

5. Catherine Guy - Quint and et al. Tacle Climate Change - Use Wood (2006).

6. DG Enterprise - Unit 4, Comprehensive Report 2002-2003 regarding the role of forest products for climate change mitigation.

7. Kakiuchi H., et al. "Titanium concentration in ocean". Journal of Radio analytical and Nuclear Chemistry 239/3, 523 (1999).

8. Scott Williams, Titanium supply consideration - Los Alamos National laboratory.
9. Global Uranium resources to meet projected demand - International Atomic Energy Agency (2006).

10. Peter Koch. "Wood versus Non-wood Materials in US residential construction: Some Energy Related Global Implication". Forest Products Journal 42.5 (1992): 31-42.

Volume 3 Issue 11 November 2019 (C) All rights are reserved by $S$ K Nath. 